\title{
Periovulatory gonadotrophin and ovarian steroid patterns in sheep of breeds with differing fecundity
}

\author{
B. M. Bindon*, M. R. Blanc, J. Pelletier, M. Terqui and J. Thimonier \\ Laboratoire de Physiologie de la Reproduction, Centre de Recherches de Tours, Nouzilly 37380 , \\ France
}

\begin{abstract}
Summary. Plasma hormone concentrations before and during luteolysis (induced by injection of a prostaglandin analogue on Day 10 or 11 of the cycle), during the period of preovulatory follicle growth and ovulation were examined in sheep with known differences in ovulation rate (Romanov, Préalpes, Romanov $\times$ Préalpes cross, Ile de France). The number of CL at the time of treatment and the ovulation rate in the ensuing cycle were established by endoscopy. Plasma concentrations of FSH, LH, progesterone and total oestrogen were measured by radioimmunoassays in the 3 days before PG injection, then hourly for the $24 \mathrm{~h}$ after PG injection and 2hourly for a further period up to about $100 \mathrm{~h}$ after PG injection. The onset and duration of oestrus were also recorded.

Although breed differences were observed for many of the features studied, only the intervals between oestrus and the LH peak and between PG injection and the LH peak were significantly correlated with ovulation rate.
\end{abstract}

\section{Introduction}

It is well established that gonadotrophins are responsible for follicular growth and ovulation in most mammals, including sheep, although it is not yet known whether quantitative differences in plasma gonadotrophins and ovarian steroid hormones in sheep are related to the number of ovulations. In sheep, and in other domestic livestock, the question is important in research programmes that evaluate the use of hormone measurements as an aid to identification and selection of animals with high genetic merit for fertility and fecundity. A difficulty that arises in such studies, however, is the choice of when to make the hormone measurements, how frequently and for how long. In the present study we examined LH, FSH, progesterone and oestrogen concentrations in sheep genetically different with respect to ovulation numbers during the period from the end of the luteal phase of one oestrous cycle until the completion of the ovulation that follows. Part of this work has been presented in abstract form (Bindon, Blanc, Pelletier, Terqui \& Thimonier, 1975).

Previous studies with similar objectives include those of Thimonier \& Pelletier (1971) and Land, Pelletier, Thimonier \& Mauleon (1973), although these involved other breeds of sheep and examined LH only.

\section{Materials and Methods}

The ewes were taken from a flock comprising 8 Romanov, 12 Préalpes du Sud (Préalpes), 12 Ile de France and 20 Romanov $\times$ Préalpes crosses. The Romanov breed has a mean litter size of 2.5-2.6 (Desvignes, 1971) while the Préalpes and Ile de France have litter sizes of 1.5 and

* Present address: CSIRO, Division of Animal Production, Private Mail Bag, Armidale, New South Wales 2350, Australia. 
1.3 respectively (Desvignes \& Thimonier, 1971). They were $2-4$ years old at the time of the investigation in October-November 1974 and were kept entirely indoors at Tours, France $\left(47^{\circ} 30^{\prime} \mathrm{N}\right)$ on a diet providing daily intakes of $400 \mathrm{~g}$ dehydrated lucerne, $200 \mathrm{~g}$ dehydrated maize and cereal straw ad libitum. The animals were the progeny of at least 4 sires of each breed.

At the time of the experiment daylength was approximately $8 \mathrm{~h} 45 \mathrm{~min}$ and the temperature in the animal house $5-15^{\circ} \mathrm{C}$.

\section{Experimental procedure}

The experimental plan is outlined in Text-fig. 1. For ease of blood sampling the ovarian cycles of the ewes were synchronized by treatment with progestagen-impregnated pessaries $(40 \mathrm{mg}$ Cronolone: SC 9880 , G. D. Searle, France). Of the 52 ewes treated with pessaries 34 were still closely synchronized by the time of intramuscular injection with $100 \mu$ g I.C.I. 80,996 (a prostaglandin analogue) on 26 November, i.e. Day 10.5 or 11 of a normal oestrous cycle (Day 0 $=$ day of oestrus).

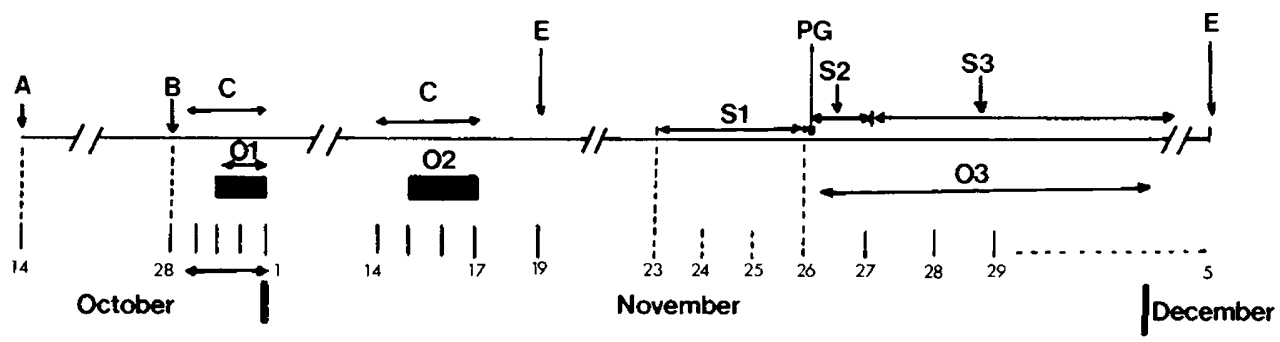

Text-fig. 1. Scheme of the experimental procedure used: A, progestagen impregnated pessary inserted at 10:00 h into all (52) ewes; B, pessary removed, 07:30 h; C, ewes examined for oestrus at 08:00 and 17:00 h; O1, oestrus occurring after pessary removal in all 52 ewes; $\mathrm{O} 2$, synchronized oestrus in 34 ewes; $E$, endoscopy examination of ovaries; PG, injection of prostaglandin analogue at 09:00 h on Day 10 or 11 of synchronized cycle; O3, occurrence of oestrus after injection of prostaglandin analogue, checked every $2 \mathrm{~h}$ until start, then every $12 \mathrm{~h}$ until end; $\mathrm{S} 1$, blood samples taken at 09:00, 12:00, 15:00 and 18:00 $\mathrm{h}$ on the days indicated; S2 blood samples taken every hour for $24 \mathrm{~h} ; \mathrm{S} 3,2$-hourly blood samples until $24 \mathrm{~h}$ after end of oestrus.

All blood samples were taken by jugular venepuncture into evacuated tubes. Oestrus was detected by using entire, aproned rams during a 20-min period every $2 \mathrm{~h}$. Blood sampling and detection of oestrus occupied 20 min every $2 \mathrm{~h}$. The animals showed no obvious signs of stress during the experiment, and their feed intake remained unchanged throughout. Ovulation number was assessed by endoscopy during barbiturate anaesthesia (Thimonier \& Mauléon, 1969) 6 days after oestrus.

This experimental design therefore permitted comparison of the following items in the 4 breeds of sheep known to be different in fecundity: (1) the luteolytic response to the prostaglandin (PG) analogue injected at a precise stage of the luteal phase; (2) the interval from PG injection to onset of oestrus and duration of oestrus; (3) the number of ovulations before and after PG analogue treatment; (4) the plasma hormone concentrations of LH, FSH, progesterone and total oestrogens in the 3 days before and the next few days after PG analogue injection, i.e. the period when preovulatory follicle growth and ovulation occur.

\section{Hormone estimations}

Within 30 min of each blood sampling, plasma was separated by centrifugation at $4{ }^{\circ} \mathrm{C}$ and then stored at $-15^{\circ} \mathrm{C}$ until assay. Unless otherwise indicated all samples were assayed for a particular hormone in a single assay to eliminate inter-assay variation. 
$L H$. Duplicate $100 \mu$ plasma samples were assayed for LH by the specific double-antibody method of Pelletier, Kann, Dolais \& Rosselin (1968). Sensitivity of this assay was $0.5 \mathrm{ng} / \mathrm{ml}$ plasma and the within-assay precision $7 \%$. The samples were assayed in two batches: the first included all samples up to the point of onset of oestrus and the second included those from the onset of oestrus until some hours after the end of oestrus. The results are expressed as ng $\mathrm{LH}$ $\mathrm{M}_{3} / \mathrm{ml}$ plasma $\left(\mathrm{LH}-\mathrm{M}_{3}=1.8 \times\right.$ the potency of NIH-LH-S1). The LH discharge was assumed to commence when $\mathrm{LH}$ concentration exceeded $6 \mathrm{ng} / \mathrm{ml}$ of plasma. The magnitude of the preovulatory LH peak was calculated as the area under the curve of the discharge and expressed as $\mathrm{ng} \mathrm{LH} / \mathrm{ml}$ plasma/h as if all the $\mathrm{LH}$ release into the blood occurred at a constant rate.

$F S H$. Plasma FSH levels were measured by an homologous radioimmunoassay using CNRS-FSH-P $_{26}$ (biologically equivalent to $40 \mathrm{mg} \mathrm{NIH-FSH-S1/mg} \mathrm{in} \mathrm{the} \mathrm{Steelman-Pohley}$ (1953) bioassay) as the reference standard and as the radioiodinated hormone. After absorption of the antiserum by purified ovine $\mathrm{LH}$, cross-reactions with ovine prolactin, GH, ACTH, TSH or LH were all less than $0.2 \%$. Assay sensitivity was $0.4 \mathrm{ng} / \mathrm{ml}$ plasma and within-assay variation $5 \%$. Dilution of plasma from a castrated ram, pituitary extracts or various grade purified ovine FSH preparations gave results parallel to those of the reference standard. The results are expressed as ng FSH-P ${ }_{26} / \mathrm{ml}$ plasma.

Progesterone. The radioimmunoassay used was that described by Palmer \& Jousset (1975). The antiserum was raised in rabbits to progesterone-11-hemisuccinate-BSA. The between- and within-assay coefficients of variation for the assay were $5.4 \%$ and $3.3 \%$ respectively. Progesterone determinations, on duplicate $0.5 \mathrm{ml}$ plasma extract samples, were obtained only for Samples 1-50, since these were expected to encompass the period of luteolysis.

Total oestrogens. The method used for total oestrogen was the radioimmunoassay described by Terqui, Delouis, Thimonier \& Ortavant (1975) and by Palmer \& Terqui (1977); it included an enzymic hydrolysis and employed an antiserum raised in rabbits to oestrone conjugated to BSA at position 17 . The cross-reactions were $100 \%$ with oestrone, $75 \%$ with 16 -ceto-oestradiol$17 \beta, 65 \%$ with $16 \alpha$-hydroxyoestrone and $39 \%$ with oestradiol-17 $\beta$. The results are expressed as pg total oestrogen $/ \mathrm{ml}$ plasma. Intra-assay variability was $7 \%$ for $2 \mathrm{ng} / \mathrm{ml}(n=10)$ and the interassay variability $17 \%$ for $3.8 \mathrm{ng} / \mathrm{ml}(n=20)$.

\section{Statistical analyses}

For each animal the following observations were included in the analysis: time (h) from PG analogue injection to onset of oestrus; duration (h) of oestrus; ovulation rate (no. of $C L$ ) in cycle before PG analogue injection; ovulation rate (no. of CL) after PG analogue injection; mean LH level in plasma samples taken $-24,-48$, and $-72 \mathrm{~h}$ before $\mathrm{PG}$ analogue injection; baseline value of LH, i.e. mean of all plasma samples outside the region of the $\mathrm{LH}$ peak; total $\mathrm{LH}$ release during the LH peak $(\mathrm{ng} / \mathrm{ml} / \mathrm{h})$; peak value of $\mathrm{LH}$ recorded; interval $(\mathrm{h})$ from onset of oestrus to the LH peak; interval (h) from PG analogue injection to LH peak: mean FSH in samples $-24,-48$ and $-72 \mathrm{~h}$ before $\mathrm{PG}$ analogue injection; mean FSH from time of $\mathrm{PG}$ analogue injection until onset of oestrus; mean FSH during oestrus; mean FSH from end of oestrus to last plasma sample (i.e. approximately $24 \mathrm{~h}$ after end of oestrus): maximum value of FSH recorded; mean progesterone level in Samples 1-12, before PG analogue injection; time (h) from PG analogue injection to the point where a $50 \%$ reduction in the progesterone level in Samples 1-12 was achieved; time (h) from PG analogue injection until completion of luteolysis, taken as the point where in two consecutive samples progesterone levels were $<0.5 \mathrm{ng} / \mathrm{ml}$; mean total oestrogen in plasma samples taken -15 and $-18 \mathrm{~h}$ before $\mathrm{PG}$ analogue injection; mean total oestrogen level from time of PG analogue injection to onset of oestrus; mean total oestrogen level during oestrus; mean total oestrogen level during the $24 \mathrm{~h}$ after the end of oestrus; time from PG analogue injection to the total oestrogen peak value; maximum total oestrogen value recorded after PG analogue injection and before onset of oestrus; maximum 
total oestrogen value recorded during oestrus. For each of these items the mean values and their standard errors for sheep of each breed were computed and subjected to an analysis of variance for assessment of the significance of the breed effects. The pooled (i.e. across the 4 breeds) correlation coefficients for all possible combinations of the above responses were produced.

\section{Results}

\section{Oestrus and ovulation after PG analogue injection}

As shown in Table 1, Romanov ewes experienced oestrus significantly earlier than those of the other 3 breeds. There were also substantial differences in the duration of oestrus with the breeds ranking in the order Romanov $>$ Romanov $\times$ Préalpes $>$ Préalpes $>$ Ile de France.

Table 1. Oestrus and ovulation (values are mean \pm s.e.m.) in sheep of 4 breeds after injection of a prostaglandin (PG) analogue on Day 11 of the oestrous cycle

\begin{tabular}{|c|c|c|c|c|c|}
\hline \multirow[b]{2}{*}{ Breed } & \multirow{2}{*}{$\begin{array}{l}\text { No. of } \\
\text { ewes }\end{array}$} & \multirow{2}{*}{$\begin{array}{l}\text { Time to oestrus } \\
\text { (h) }\end{array}$} & \multirow{2}{*}{$\begin{array}{l}\text { Duration of } \\
\text { oestrus (h) }\end{array}$} & \multicolumn{2}{|c|}{ Mean ovulation rate } \\
\hline & & & & Before PG & After PG \\
\hline Romanov & $8^{*}$ & $36 \cdot 0 \pm 1 \cdot 9^{a}$ & $52 \cdot 7 \pm 3 \cdot 1^{a}$ & $2 \cdot 86 \pm 0.23^{a}$ & $2.71 \pm 0.19^{\mathrm{a}}$ \\
\hline Préalpes & 8 & $43.5 \pm 1.8^{b}$ & $39.0 \pm 2.9^{b}$ & $1.75 \pm 0.22^{c}$ & $2.00 \pm 0.18^{c}$ \\
\hline Romanov $\times$ Préalpes & $10^{*}$ & $43 \cdot 3 \pm 1 \cdot 7^{b}$ & $45 \cdot 0 \pm 2 \cdot 7^{\mathrm{b}}$ & $2.33 \pm 0.20^{b}$ & $2.44 \pm 0.17^{b}$ \\
\hline Ile de France & 8 & $44.0 \pm 1.8^{b}$ & $31 \cdot 0 \pm 2 \cdot 9^{c}$ & $1.50 \pm 0.22^{\mathrm{c}}$ & $1.63 \pm 0.18^{c}$ \\
\hline $\begin{array}{l}\text { Significance of } \\
\text { difference between } \\
\text { breeds }\end{array}$ & & $P<0.05$ & $P<0.01$ & $P<0.01$ & $P<0.01$ \\
\hline
\end{tabular}

* One animal was eliminated from this group for measurements other than ovulation rate before PG; see text.

$\dagger$ Groups with different superscripts differ significantly.

Ovulation rate was also ranked in this order, before the PG analogue injection and in the next cycle, but in none of the breeds did the ovulation rate differ at the two times.

The mean lengths of the oestrous cycle were $16 \cdot 4,16 \cdot 4,16 \cdot 2$ and $16 \cdot 6$ days for Romanov, Préalpes, Romanov $\times$ Préalpes and Ile de France breeds and the cycle following PG analogue injection was of normal length. Abnormal responses were noted in 2 ewes. One Romanov ewe remained in oestrus for 8 days and one Romanov $\times$ Préalpes ewe failed to experience complete luteolysis: data for both ewes were eliminated from part of the analyses.

Table 2. Progesterone concentrations (mean \pm s.e.m.) in sheep of 4 breeds before and after injection of the prostaglandin (PG) analogue

\begin{tabular}{|c|c|c|c|}
\hline Breed & $\begin{array}{l}\text { Progesterone conc. } \\
(\mathrm{ng} / \mathrm{ml}) \text { before } \mathrm{PG}^{*}\end{array}$ & $\begin{array}{l}\text { Time }(\mathrm{h}) \text { to achieve } \\
50 \% \text { reduction in } \\
\text { progesterone conc. }\end{array}$ & $\begin{array}{c}\text { Time (h) from PG to } \\
\text { luteolysis } \ddagger\end{array}$ \\
\hline Romanov & $3 \cdot 50 \pm 0 \cdot 21^{\mathrm{a}}$ & $3.43 \pm 0.82^{\mathrm{a}}$ & $20 \cdot 0 \pm 1 \cdot 6^{\mathrm{a}}$ \\
\hline Préalpes & $2 \cdot 24 \pm 0 \cdot 19^{b}$ & $5.50 \pm 0.77^{\mathrm{b}}$ & $15 \cdot 5 \pm 1 \cdot 5^{b}$ \\
\hline Romanov $\times$ Préalpes & $2.47 \pm 0.19^{b}$ & $6.22 \pm 0.72^{\mathrm{b}}$ & $14 \cdot 1 \pm 1 \cdot 4^{b}$ \\
\hline lle de France & $2.53 \pm 0.19^{b}$ & $6.88 \pm 0.77^{b}$ & $14.9 \pm 1.5^{\mathrm{b}}$ \\
\hline $\begin{array}{l}\text { Significance of breed } \\
\text { differences }{ }^{\dagger}\end{array}$ & $P<0.01$ & $P<0.05$ & $P<0.05$ \\
\hline
\end{tabular}

* Twelve (12) samples taken over 3 days.

$\dagger$ Groups with different superscripts differ significantly.

$\ddagger$ Two consecutive samples $<0.5 \mathrm{ng}$ progesterone $/ \mathrm{ml}$. 


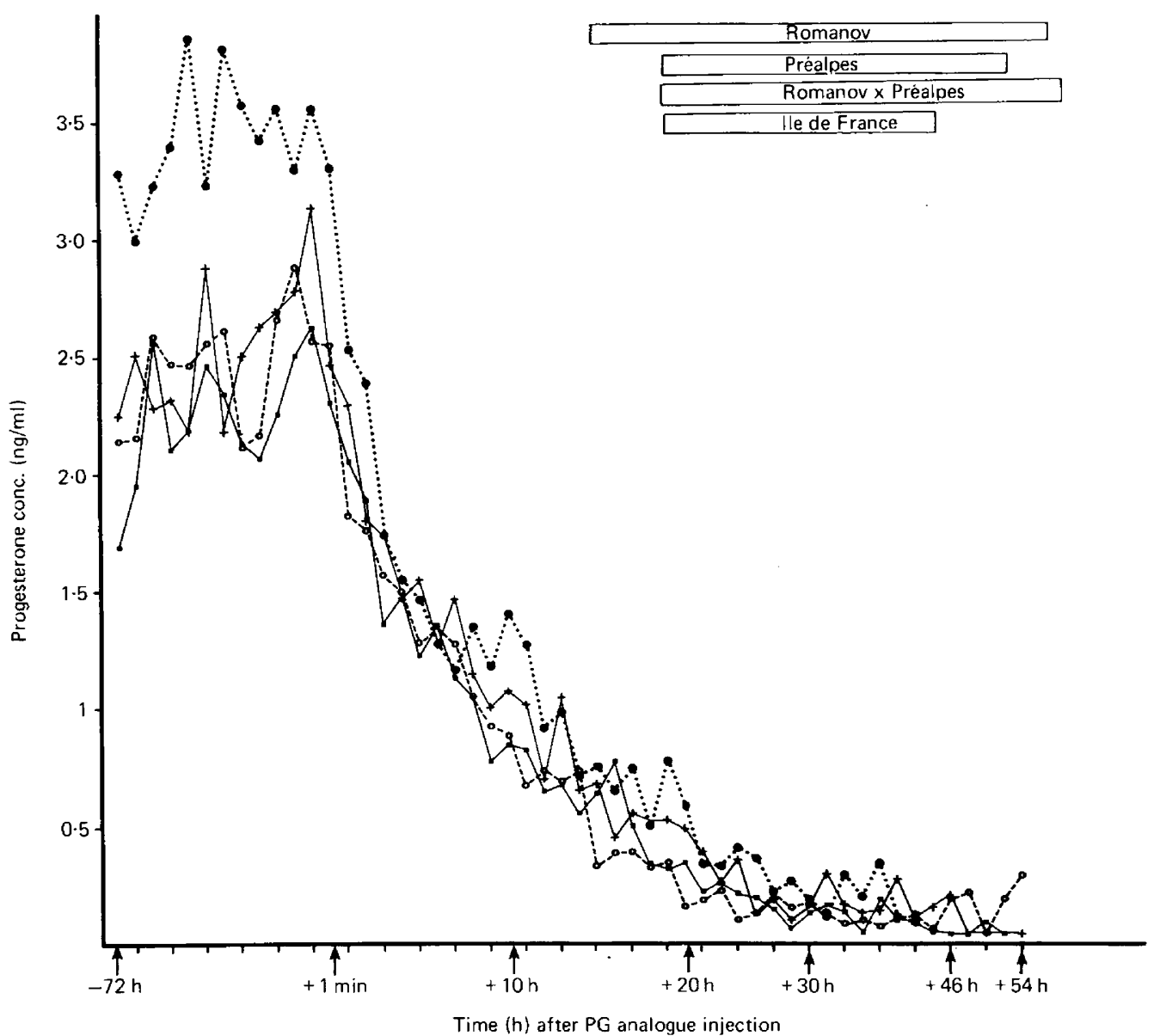

Text-fig. 2. Mean plasma progesterone concentrations in Romanov (0......), Préalpes (ㅁ), Romanov $\times$ Préalpes cross $(0---O)$, and Ile de France $(+-+)$ ewes before and after PG analogue injection. The duration of oestrus for each breed is shown by the horizontal bars.

\section{Plasma progesterone}

Mean progesterone concentrations before and during luteolysis for the 4 breeds are shown in Text-fig. 2. The data are further analysed in Table 2. It is clear that the Romanov ewes had significantly higher progesterone values than those of the other breeds, and although the early rate of luteolysis was faster in this breed, the time required for complete luteolysis was significantly longer for these animals.

\section{Plasma total oestrogen}

The 7 separate estimates of total oestrogen activity for the 4 breeds are summarized in Table 3 and the sequential pattern for each breed shown in Text-fig. 3. During most periods of the experiment the Ile de France and Romanov $\times$ Prealpes ewes had higher concentrations than the other ewes. Soon after PG analogue injection there was an abrupt discharge of total oestrogen. The only other consistent feature was the peak value of total oestrogen recorded during oestrus: there was a tendency for this to coincide with the LH peak, although this was not consistent for 
Table 3. Mean \pm s.e.m. total oestrogen $\left(\mathrm{E}_{\mathrm{T}}\right)$ levels $(\mathrm{gg} / \mathrm{ml})$ in sheep of 4 breeds after luteolysis induced by injection with a prostaglandin (PG) analogue

\begin{tabular}{|c|c|c|c|c|c|c|c|}
\hline Breed & $\begin{array}{c}\mathrm{E}_{\mathrm{T}} 15 \text { and } \\
18 \mathrm{~h} \text { before } \\
\mathrm{PG}\end{array}$ & $\begin{array}{c}E_{\mathrm{T}} \text { from } P G \\
\text { to onset of } \\
\text { oestrus }\end{array}$ & $\begin{array}{c}\mathrm{E}_{\mathrm{T}} \text { during } \\
\text { oestrus }\end{array}$ & $\begin{array}{c}\mathrm{E}_{\mathrm{T}} \text { during } \\
24 \mathrm{~h} \text { after } \\
\text { end of } \\
\text { oestrus }\end{array}$ & $\begin{array}{l}\text { Time }(\mathrm{h}) \\
\text { from PG to } \\
\text { peak } \mathrm{E}_{\mathrm{T}}\end{array}$ & $\begin{array}{l}\text { Maximum } E_{\mathrm{T}} \\
\text { recorded } \\
\text { after } \mathrm{PG}\end{array}$ & $\begin{array}{c}\text { Maximum } \\
\mathrm{E}_{\mathrm{T}} \text { during } \\
\text { oestrus }\end{array}$ \\
\hline Romanov & $67 \pm 18^{a}$ & $125 \pm 16^{\mathrm{a}}$ & $119 \pm 24^{\mathrm{a}}$ & $105 \pm 15^{a}$ & $7.86 \pm 0.92$ & $340 \pm 49^{\mathrm{a}}$ & $228 \pm 54^{\mathrm{a}}$ \\
\hline Préalpes & $119 \pm 17^{\mathrm{a}}$ & $130 \pm 15^{\mathrm{a}}$ & $109 \pm 22^{\mathrm{a}}$ & $78 \pm 14^{a}$ & $11.25 \pm 0.86$ & $299 \pm 45^{\mathrm{a}}$ & $242 \pm 50^{\mathrm{a}}$ \\
\hline $\begin{array}{c}\text { Romanov } \times \\
\text { Préalpes }\end{array}$ & $159 \pm 16^{b}$ & $164 \pm 14^{b}$ & $191 \pm 21^{b}$ & $146 \pm 13^{b}$ & $8 \cdot 11 \pm 0 \cdot 81$ & $404 \pm 43^{b}$ & $413 \pm 48^{b}$ \\
\hline Ile de France & $143 \pm 17^{b}$ & $186 \pm 15^{b}$ & $189 \pm 22^{b}$ & $164 \pm 14^{b}$ & $8.76 \pm 0.86$ & $533 \pm 45^{b}$ & $351 \pm 50^{\mathrm{b}}$ \\
\hline $\begin{array}{l}\text { Significance of } \\
\text { breed } \\
\text { differences* }\end{array}$ & $P<0.01$ & $P<0.05$ & $P<0.05$ & $P<0.001$ & N.S. & $P<0.01$ & $P<0.05$ \\
\hline
\end{tabular}

* Groups with different superscripts differ significantly.

all sheep within a breed. The peak concentration was recorded at an average time of $-0 \cdot 66$, $-2 \cdot 50,-3.6$ and +5.25 h from the $\mathrm{LH}$ peak for the Romanov, Prealpes, Romanov $\times$ Prealpes and Ile de France ewes respectively.

\section{Plasma FSH levels}

The results, summarized in Table 4, show that only minor breed differences were observed. The Romanov and Ile de France ewes tended to have higher FSH levels before the PG analogue injection and before, during and after oestrus. The ewes of lowest fecundity (Ile de France) had, in general, the highest overall FSH concentrations, although these were not always significantly higher than in the Romanovs. Most ewes (28 out of 32 examined) showed an increase in FSH concentration that coincided with the LH discharge, although this was not as clear-cut as reported elsewhere (see Hay \& Moor, 1975). Most animals also showed an elevation of FSH values in the period after the end of oestrus, corresponding to Days 1 and 2 of the subsequent cycle. The actual levels of FSH reported here (i.e. $2-25 \mathrm{ng} / \mathrm{ml}$ ) are lower than those described by other investigators, perhaps because of the different FSH standard used.

Table 4. Pre- and post-ovulatory plasma FSH concentrations (mean \pm s.e.m.) in sheep of 4 breeds after luteolysis induced by a prostaglandin (PG) analogue

\begin{tabular}{|c|c|c|c|c|c|}
\hline \multirow[b]{2}{*}{ Breed } & \multicolumn{5}{|c|}{ FSH response $(\mathrm{ng} / \mathrm{ml})$} \\
\hline & $\begin{array}{c}\text { At } 24,48 \text { and } \\
72 \mathrm{~h} \text { before } \\
\text { PG }\end{array}$ & $\begin{array}{c}\text { From PG to } \\
\text { onset of } \\
\text { oestrus }\end{array}$ & $\begin{array}{l}\text { During } \\
\text { oestrus }\end{array}$ & $\begin{array}{l}\text { From end of } \\
\text { oestrus to last } \\
\text { sample }\end{array}$ & $\begin{array}{l}\text { Maximum conc. } \\
\text { recorded }\end{array}$ \\
\hline Romanov & $9.72 \pm 0.96$ & $8 \cdot 16 \pm 0.91^{\mathrm{a}}$ & $8.47 \pm 1.06^{a}$ & $7 \cdot 02 \pm 1 \cdot 19^{a}$ & $13 \cdot 57 \pm 1.55$ \\
\hline Préalpes & $7.89 \pm 0.90$ & $6.29 \pm 0.85^{b}$ & $6.81 \pm 0.99^{a}$ & $7 \cdot 28 \pm 1 \cdot 11^{\mathrm{a}}$ & $12.06 \pm 1.45$ \\
\hline Romanov $\times$ Prealpes & $7 \cdot 14 \pm 0.86$ & $6 \cdot 39 \pm 0 \cdot 80^{b}$ & $7.83 \pm 0.93^{a}$ & $8.96 \pm 1.05^{a}$ & $13.05 \pm 1.36$ \\
\hline Ile de France & $9.23 \pm 0.91$ & $8.78 \pm 0.85^{a}$ & $10.98 \pm 0.99^{b}$ & $10 \cdot 59 \pm 1 \cdot 11^{b}$ & $16.59 \pm 1.45$ \\
\hline $\begin{array}{l}\text { Significance of breed } \\
\text { differences }\end{array}$ & N.S. & $P<0.05$ & $P<0.05$ & $P<0.05$ & N.S. \\
\hline
\end{tabular}

* Groups with different superscripts differ significantly. 

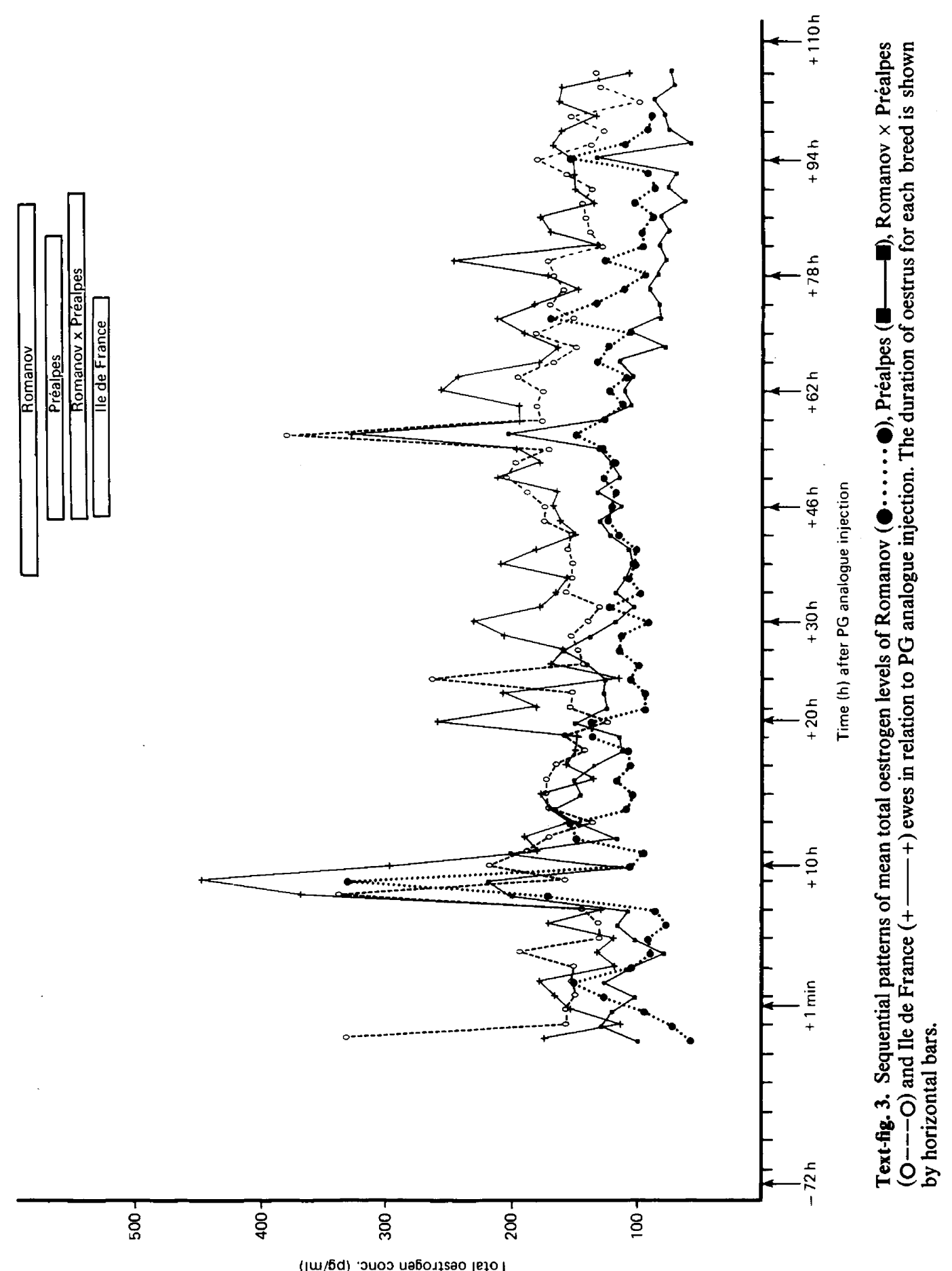
Table 5. Preovulatory plasma LH concentrations (mean \pm s.e.m.) in sheep of 4 breeds after luteolysis induced by a prostaglandin (PG) analogue

\begin{tabular}{|c|c|c|c|c|c|c|c|}
\hline Breed & $\begin{array}{l}\text { No. of } \\
\text { ewes }\end{array}$ & $\begin{array}{c}\text { LH } \\
(\mathrm{ng} / \mathrm{ml}) \\
\text { before } \mathrm{PG}^{*}\end{array}$ & $\begin{array}{c}\text { Baseline } \\
\text { LH } \\
(\mathrm{ng} / \mathrm{ml})^{\dagger}\end{array}$ & $\begin{array}{l}\text { Total } \mathrm{LH} \\
\text { released in } \\
\mathrm{LH} \text { peak } \\
(\mathrm{ng} / \mathrm{ml} / \mathrm{h})\end{array}$ & $\begin{array}{c}\text { Peak } \\
\text { LH level } \\
\text { (ng) }\end{array}$ & $\begin{array}{l}\text { Time from } \\
\text { onset of } \\
\text { oestrus to } \\
\text { LH peak (h) }\end{array}$ & $\begin{array}{l}\text { Time from } \\
\text { PG to LH } \\
\text { peak } \\
\text { (h) }\end{array}$ \\
\hline Romanov & 7 & $1.44 \pm 0.09$ & $1.42 \pm 0.32$ & $151 \pm 33$ & $33.1 \pm 6.0$ & $25 \cdot 1 \pm 1 \cdot 7^{a}$ & $61 \cdot 1+2 \cdot 3^{a}$ \\
\hline Préalpes & 8 & $1.34 \pm 0.08$ & $1.21 \pm 0.30$ & $223 \pm 31$ & $42 \cdot 1 \pm 5 \cdot 6$ & $13.5 \pm 1.6^{b}$ & $57.0 \pm 2 \cdot 1^{\mathrm{a}}$ \\
\hline $\begin{array}{c}\text { Romanov } \times \\
\text { Préalpes }\end{array}$ & 9 & $1.23 \pm 0.08$ & $1.12 \pm 0.28$ & $209 \pm 29$ & $32 \cdot 6 \pm 5 \cdot 3$ & $17 \cdot 3 \pm 1 \cdot 5^{b}$ & $60 \cdot 1 \pm 2 \cdot 0^{\mathrm{a}}$ \\
\hline lle de France & 8 & $1.35 \pm 0.08$ & $1.13 \pm 0.30$ & $171 \pm 31$ & $35 \cdot 3 \pm 5 \cdot 6$ & $7 \cdot 0 \pm 1.6^{\mathrm{c}}$ & $51 \cdot 0 \pm 2 \cdot 1^{b}$ \\
\hline $\begin{array}{l}\text { Significance of } \\
\text { breed } \\
\text { differences } \ddagger\end{array}$ & & N.S. & N.S. & N.S. & N.S. & $P<0.001$ & $P<0.05$ \\
\hline
\end{tabular}

* Mean of 12 samples on Days 8,9 and 10 .
† All values except those of the LH peak.
‡ Groups with different superscripts differ significantly.

\section{Plasma LH levels}

There were no significant breed differences in LH levels during Days 8-10 of the cycle (i.e. before PG injection) nor in the overall baseline value (Table 5). The total $\mathrm{LH}$ released and the peak level recorded during the preovulatory peak were also similar for the 4 breeds. There were, however, substantial breed differences in the timing of the $\mathrm{LH}$ peak. Although Romanov ewes showed oestrus earlier than the other groups (Table 1) there were still significant breed differences when the interval examined was that from PG analogue injection to LH peak: the ewes with the higher ovulation rates had a longer interval between injection and LH release than the Ile de France ewes.

A small discharge of LH occurred in all animals $7-8 \mathrm{~h}$ after PG analogue injection. The discharge, expressed as a percentage increase of the level of LH before injection, was larger for the Romanov and the Romanov $\times$ Préalpes ewes (75 and 129\% respectively) than for the

Table 6. Correlation coefficients, based on untransformed data, for ovulation rate and various measurements after induction of luteolysis by $P G$ analogue injection

\begin{tabular}{lc}
\hline \multicolumn{1}{c}{ Preovulatory measurement } & $\begin{array}{c}\text { Correlation coefficient* } \\
\text { with ovulation rate }\end{array}$ \\
\hline Interval from PG to oestrus & -0.05 \\
Duration of oestrus & +0.23 \\
Total LH release & +0.25 \\
Height of LH peak & +0.17 \\
Interval from oestrus to LH peak & +0.39 \\
Interval from PG to LH peak & +0.39 \\
Mean FSH before PG & +0.18 \\
Mean FSH between PG and oestrus & +0.13 \\
Mean FSH during oestrus & +0.09 \\
Progesterone before PG & +0.34 \\
Time from PG to luteolysis & +0.33 \\
Total oestrogen before PG & -0.22 \\
Mean total oestrogen from PG to oestrus & -0.04 \\
Mean total oestrogen during oestrus & +0.28 \\
Total oestrogen peak during oestrus & +0.34 \\
\hline
\end{tabular}

${ }^{*} r$ value for $P<0.05=0.38 ; P<0.01=0.49$. 
Préalpes and Ile de France ewes (68 and 60\% respectively). The biological significance of the discharge is unknown.

\section{Correlation between preovulatory measurements and ovulation rate}

In Table 6 the correlation coefficients for ovulation rate following PG analogue injection and a selection of preovulatory measurements are presented. The largest of the coefficients barely reaches statistical significance.

\section{Discussion}

The main purpose of this investigation was to study the quantitative relationships between plasma hormone concentrations and ovulation rate in sheep. It is not possible to assume that the hormone patterns reported here are necessarily the same as in the normal oestrous cycle, because luteolysis was induced several days earlier than would occur in a normal cycle. Following luteolysis, however, the ewes of the four breeds were shown to have a mean ovulation rate not significantly different from that of the previous cycle. To this extent, the expected genetic differences were preserved in this experimental design. Observations before and after PG analogue injection confirm the higher ovulation rate of Romanov ewes (Table 1) and demonstrate that the ovulation rate of the Romanov $\times$ Prealpes ewes falls mid-way between that of the parent breeds. This supports the conclusion of Land et al. (1973) that the genetic differences in ovulation rate of these sheep are largely additive.

Our results confirm the luteolytic properties of the PG analogue (I.C.I. 80,996: 16-aryloxyprostaglandin) which have been described by Challis, Foster, Furr, Robinson \& Thorburn (1975) and Acritopoulou, Haresign, Foster \& Lamming (1977). The additional points of interest in the present experiment were the earlier onset of oestrus in the Romanov ewes and the significantly longer time required for complete luteolysis in these animals. In ewes of the other 3 breeds the rate of luteolysis was similar to that described by other investigators (e.g. Baird \& Scaramuzzi, 1975). It is not clear whether this difference is solely because most Romanov ewes had $3 \mathrm{CL}$ at the time of PG analogue injection or whether it reflects other characteristics of the Romanov breed. Larger doses of PG might accelerate luteolysis in sheep with $3 \mathrm{CL}$. These points may have practical significance in synchronization programmes, although it is not known whether time of ovulation was different in the Romanov ewes.

Despite the longer luteolysis the Romanov ewes showed oestrus earlier than did the other ewes, although the Romanovs had the lowest total oestrogen levels before and after injection of the PG analogue. The longer duration of oestrus in the Romanov ewes confirms the work of Land et al. (1973) on this breed and supports the general view (Dunlop \& Tallis, 1964; Land, 1970; Hanrahan \& Quirke, 1975) that duration of oestrus is positively correlated with litter size and ovulation rate. In the present study (see Table 6) duration of oestrus showed a small, positive correlation $(r=+0 \cdot 23)$ with ovulation rate. The duration of oestrus was not, however, correlated with total oestrogen values. The average total oestrogen level during oestrus and the peak value recorded during oestrus were in fact negatively correlated $(r=-0.32$ and $-0 \cdot 30$ respectively) with duration of oestrus. It must be assumed, then, that ewes like the Romanov which show oestrus earlier, stay in oestrus longer and have the highest ovulation rate, are more sensitive to circulating oestrogens.

An important feature of the present experiment was the investigation of the relationship between FSH levels and ovulation rate. If quantitative differences in FSH are responsible for differences in the number of follicles that enter the preovulatory growth phase, produce oestrogen and ovulate, then the present study should have confirmed it. The measurements of FSH during the period that followed the PG analogue injection should have coincided with the 
period when terminal follicle growth and ovulation itself were in progress. It is clear from Table 4 that there were small breed differences in the FSH levels but these were not in the direction that might be expected. The breed with lowest ovulation rate (Ile de France) had the highest FSH levels. It therefore seems that if $\mathrm{FSH}$ levels are related to ovulation rate the present results indicate that the moment of determination of ovulation rate is not located in the 4-5 days before oestrus.

There are no other reports of attempts to relate FSH levels to breed differences in fecundity of adult sheep, although Findlay \& Bindon (1976) have shown that ewe lambs from Merinos of high fecundity have higher FSH levels than those from Merinos with low fecundity.

Breed differences were not evident in the LH measurements shown in Table 5, and similar results were reported by Thimonier \& Pelletier (1971) and Land et al. (1973). These authors also showed that the interval between onset of oestrus and $\mathrm{LH}$ discharge was longer in Romanov ewes (Land et al., 1973) or in ewes within the breed with the highest ovulation rate (Thimonier \& Pelletier, 1971). The present experiment substantiates this point and although the interval between PG analogue injection and oestrus is shorter in Romanov ewes, the interval between the injection and the LH peak is longer than in the Ile de France ewes.

It has been suggested (Hay \& Moor, 1975) that the LH discharge terminates preovulatory follicle activity, or at least the ability to secrete oestrogen. If this is true, the high fecundity animals like the Romanov would have a longer period available for preovulatory follicular development before this is brought to a halt by the LH peak. It is yet to be established, of course, whether in the normal oestrous cycle the interval between luteolysis and LH discharge is influenced by breed effects as it is after PG-induced luteolysis. Both the higher progesterone concentrations and extended luteolysis in the Romanov breed may play a significant regulatory role in the ovulation rate of the next cycle.

Based on the present investigation it must be concluded that apart from progesterone there are no consistent, positive associations between peripheral plasma levels of ovarian steroids or plasma gonadotrophins and the fecundity ranking of the 4 breeds studied. For example, although ewes of the Romanov breed regularly shed about twice as many eggs as do Ile de France ewes, they have slightly lower FSH, similar LH and significantly less total oestrogen concentrations during the period when terminal follicle growth and ovulation take place. It is also possible that the ovaries of high fecundity sheep contain more follicles, are more sensitive to a fixed quantity of gonadotrophin, or that ovarian incorporation of gonadotrophin is higher in these animals. It must also be conceded that hormonal regulation of ovulation rate may occur at times in the oestrous cycle other than those studied here.

This experiment was made possible by the approval of Monsieur R. Ortavant, former Director of the laboratory, and by the generous assistance of many staff members at Nouzilly. Special thanks are due to Monsieur C. Cornu and staff for maintenance of the experimental animals, and Ms M. Cheers and Mrs E. Shuter of CSIRO, Australia, for assistance in data analysis. Part of this work has been supported by D.G.R.S.T. (grant no. 73-7-1886). The FSH (CNRS-FSH-P ${ }_{26}$ ) was kindly supplied by Dr M. Jutisz (Gif/Yvette, France).

\section{References}

Acritopoulou, S., Haresign, W., Foster, J.P. \& Lamming, G.E. (1977) Plasma progesterone and LH concentrations in ewes after an injection of an analogue of prostaglandin F-2 $\alpha$. J. Reprod. Fert. 49, 337-340.

Baird, D.T. \& Scaramuzzi, R.J. (1975) Prostaglandin F $2 \alpha$ and luteal regression in the ewe: comparison with 16-aryloxy prostaglandin (I.C.I. 80996). Annls Biol. anim. Biochim. Biophys. 15, 161-174.

Bindon, B.M., Blanc, M.R, Pelletier, J., Terqui, M. \& Thimonier, J. (1975) Preovulatory gonadotrophins and ovarian steroid changes in French sheep breeds different in fecundity. Proc. Endocr. Soc. Aust. 18, 64, Abstr. 
Challis, J.R.G., Foster, C.S., Furr, B.J.A., Robinson, J.S. \& Thorburn, G. (1975) Prostaglandin F and steroid production in sheep after luteal regression induced with a synthetic prostaglandin analogue, ICI, cloprostenol. Acta endocr., Copenh., Suppl. 199, 247, Abstr.

Desvignes, A. (1971) La race ovine Romanov; revue bibliographique. Ann. Zootech. 20, 353-370.

Desvignes, A. \& Thimonier, J. (1971) Niveau de productivité des troupeaux ovins francais. Bull. Tech. d'Information. 257, 89-96. Ministère de l'Agriculture, France.

Dunlop, A.A. \& Tallis, G.M. (1964) The effect of length of oestrus and number of inseminations on the fertility and twinning rate of the Merino ewe. Aust.J. agric. Res. 15, 282-288.

Findlay, J.K. \& Bindon, B.M. (1976) Plasma FSH in Merino lambs selected for fecundity. J. Reprod. Fert. 46, 515-516, Abstr.

Hanrahan, J.P. \& Quirke, J.F. (1975) Repeatability of the duration of oestrus and breed differences in the relationship between duration of oestrus and ovulation rate of sheep. $J$. Reprod. Fert. 45, 29-36.

Hay, M.F. \& Moor, R.M. (1975) Functional and structural relationships in the Graafian follicle population of the sheep ovary. J. Reprod. Fert. 45, 583-593.

Land, R.B. (1970) A relationship between the duration of oestrus, ovulation rate and litter size of sheep. $J$. Reprod. Fert. 23, 49-53.

Land, R.B., Pelletier, J., Thimonier, J. \& Mauléon, P. (1973) A quantitative study of genetic differences in the incidence of oestrus, ovulation and plasma luteinizing hormone concentration in the sheep. $J$. Endocr. 58, 305-317.

Palmer, E. \& Jousset, B. (1975) Urinary oestrogen and plasma progesterone levels in non-pregnant mares. $J$. Reprod. Fert., Suppl. 23, 213-221.

Palmer, E. \& Terqui, M. (1977) Measurement of total (conjugated and unconjugated) oestrogens during follicular phase of the mare oestrous cycle. Theriogenology 7, 331-338.

Pelletier, J., Kann, G., Dolais, J. \& Rosselin, G. (1968) Dosage radioimmunologique de l'hormone lutéinisante plasmatique de mouton. Mise au point de la technique de dosage. C. r. hebd. Séanc Acad. Sci., Paris D 266, 2291-2294.

Steelman, S.L. \& Pohley, F.M. (1953) Assay of follicle stimulating hormone based on augmentation with human chorionic gonadotrophin. Endocrinology 53, 604-616.

Terqui, M., Delouis, C., Thimonier, J. \& Ortavant, R. (1975) Relations entre les oestrogènes au cours de la gestation, le poids à la naissance et la croissance ultérieure des veaux de race Charolaise. C. $r$. hebd. Séanc Acad. Sci., Paris D 280, 2789-2792.

Thimonier, J. \& Mauléon, P. (1969) Variations saisonnières du comportement d'oestrus et des activités ovarienne et hypophysaire chez les ovins. Annls Biol. anim. Biochim. Biophys. 9, 233-250.

Thimonier, J. \& Pelletier, J. (1971) Difference génétique dans la décharge ovulante (LH) chez les Brebis de race Ile de France; relations avec le nombre d'ovulations. Annls Biol. anim. Biochim. Biophys. $11,559-567$. 